\title{
THE EFFECTIVENESS OF ELECTRONIC INFORMATION MEDIA AS HEALTH PROMOTION FOR EXCLUSIVE BREASTFEEDING: A SYSTEMATIC REVIEW
}

\author{
Budi Susilawati, Ellyda Rizki Wijhati
}

Study Program in Midwifery, Universitas ‘Aisyiyah Yogyakarta

\begin{abstract}
Background: The World Health Organization (WHO) strongly recommend exclusive breastfeeding for infants until they reach six months of age. Breast milk contains antibodies that help infants fight off viruses and bacteria. Breastfeeding lowers infants' risk of having asthma or allergies. The Indonesian government had set a national target of exclusive breastfeeding of $80 \%$. However, Indonesia failed to reach the intended target with only $30.2 \%$ achieved. This study aimed to statistically review the effectiveness of electronic information media as health promotion for exclusive breastfeeding.

Subjects and Method: A systematic review was conducted by searching articles from PubMed and Science Direct databases, from 2011 to 2019. The keywords were "electronic media", "information", and "exclusive breastfeeding". The data were reviewed using PRISMA flow diagram.

Results: Various electronic information media had been used around the world, including leaflet, audio-visual media, website, cell phone, and video. Some models had been developed to promote exclusive breastfeeding, including breastfeeding peer counselors (BPC). BPC had been expected to increase knowledge, attitude, and practice of exclusive breastfeeding.

Conclusion: Various electronic information media are effective to promote exclusive breastfeeding.

Keywords: electronic information media, exclusive breastfeeding, health promotion

Correspondence:

Budi Susilawati. Study Program in Midwifery, Universitas 'Aisyiyah Yogyakarta, Yogyakarta, Indonesia. Email: bsusilawati75@ugm.ac.id. Mobile: 085101345850.
\end{abstract}

The $6^{\text {th }}$ International Conference on Public Health Best Western Premier Hotel, Solo, Indonesia, October 23-24, 2019 | 184 